\section{"Hard" Facts and "Soft" Sources: Literature as Historical Source Material?}

\section{By Dorothy Burton Skårdal}

University of Oslo

Kristian Hvidt's paper, "Fact and Fiction: A Case for the Complementary Study of History and Literature," is itself a document in the history of history, at least the history of historical research in Scandinavia within the past generation. It is yet another sign that the dominance of techniques of quantification in his field of emigration history is beginning to be questioned, as its practitioners at last realize the severe limitations of their approach. Not that computer techniques applied to "hard" data will pass away, far from it! These methods provide a more reliable basis for certain types of factual generalizations than was possible before, and I value them highly for that reason. During their heyday, however, computer historians took for granted that their methodology was the sole legitimate one in the study of the past: "Only quantification can secure that the conclusion really mirrors the reality that the historians want to describe," as Hvidt puts it. The social sciences in general have gone through the same period of attempting to become exact science on the model of the natural sciences, with the same reaction now taking place. Quantitative methods applied to "hard" data can never deal with more than quite limited areas of human life. Has Hvidt finally discovered this? If so, I find his mea culpa both too little and too late. I also find some confusion of terminology and concepts in his paper that hinder his attempt "to clear up ... the relation between studies in literature and history."

His use of some key terms implies assumptions that I must criticize. "There are historical relations which can never be described by historical source material," he says, as though "historical source material" can mean only "hard" data. Later he mentions "the 'oldfashioned" soft sources, letters, diaries, etc." which computer historians have tended to reject. I cannot make out whether Hvidt would now readmit such sources because he does not mention them again, but the question is of great importance to me because I view literature as neither more nor less than another kind of "soft" source requiring its own methodology but containing much more historical evidence than Hvidt allows. I heartily disagree with his statement that "reliable source material does not exist" for that essential part of real life which historians cannot catch because it is "the area of feelings, of psychological effects, of environment, etc." Analysis of these factors in literature can be a complementary discipline to history, he says, but cannot be used to reconstruct facts outside this area. "(T)he novel or the short story can be used as an illustration of reality but ... it cannot be used as a historical source."

Does Hvidt maintain, then, that history cannot deal with psychology, feelings, environment? And what on earth does he mean by environment? My dictionary defines the term as "the total of circumstances that affect and influence the growth and development of organisms, specifically: a) the combination of external or extrinsic physical conditions that affect and influence the growth and development of organisms. b) The complex of social and cultural conditions affecting the nature of an individual or community." I can see no difference between definition a) and what Hvidt calls facts, which he says it is the business of history to reconstruct. But then environment in this sense cannot be included in his list of subjective elements of real life beyond the power of historians to treat. In its meaning b), social and cultural conditions, surely the influence of environment on events in all periods of the past is beyond question. In both meanings the study of environment is the very stuff of history. I cannot believe that Hvidt means what he says here.

I am also troubled by his phrase reconstruct facts. Like many historians, he seems to assume that facts are things out there in the real world totally independent of human thinking about them, waiting only to be found. History then is dedicated to the end of reconstructing facts about human events as they "really happened." Without going into the challenge to such naive empiricism developed in philosophy ever since Kant, I would like to draw attention to the divergence of eyewitness accounts of a simple event like an accident in the present - how difficult it is to establish "what really happened" even when we personally see and/or participate in it. The historian is limited to fragmentary accounts of imperfect witnesses and to even more fragmentary statistical records whose accuracy is questionable in many cases. In his study of these the historian is also limited by the way his own mind works. In spite of his efforts to be objective and impersonal, his way of thinking about his world, including his professionl methodology, is 
molded by the culture he is part of, and by his position in that culture. Every historian necessarily constructs what he calls facts as well as reconstructs them. Computer historians are not exempt from the general human law that what is present in our consciousness has been interpreted by it.

Therefore I cannot accept Hvidt's implied definition of history. This he does not discuss directly, but his fable seems based on assumptions about the nature and goal of history with which I disagree. This fable makes History the eldest son of Mother Humanities, but how old is he? The only figure we get is 150 years, plus perhaps some decades. At some point History married a daughter of the Social Sciences. Was it then he turned onto the quantitative path leading to computerism, striving for objectivity and "representativity" through quantification of "hard" data only? Although Hvidt complains about how dull this History has turned out to be, it seems to me that he still holds this version of history to be the only acceptable one. Social history is his son (does that make the son acceptable, even though he uses "soft" sources?), but the only other kind of history mentioned is the lateborn and unaccepted History of Civilization, who I think would have made better sense as another son of History rather than his brother.

Are we to conclude that in Hvidt's opinion no acceptable history can be written about periods that lack quantifiable source materials in sufficient quantity? Since they were born so long before History was, can Herodotus or Bede or Gibbon be called historians at all? A much older fable makes history one of the muses, sister to the other arts that have existed since the beginning of measured time. I would prefer a combination of the two fables, making history an ancient art that has more recently been adopted into the social sciences but that must remain the least exact of them all because of its oldest lineage and its broadest subject matter. I maintain that history is both social science and art, interpreting life imperfectly through the consciousness of the historian who uses words like an author, but who is bound to source materials by methods that approach those of science in the evaluation of evidence and the construction and testing of hypotheses in order to reach logical conclusions. Hvidt's kirid of history is so deadly dull because it has deliberately abandoned all aspects of art in the name of exactness, and thereby falsified the human life that it is trying to "reconstruct." I hold that Hvidt's kind of history is only one of many kinds, far from being father to them all.

For human life is not dull, far from it! Having never believed that what can't be counted doesn't count, I am free to insist that the proper subject matter of history is all human life of the past, insofar as records of that life have survived. Any records, all records - "hard" and "soft"! My kind of history can't afford to reject any sources because its goal is to understand as much as possible about the past, focusing on different periods not just to reconstruct their "facts" but to attempt to portray their unique quality, their distinctive characteristics, their typical consciousness - on their own premises, not ours - to the extent possible. This history will always be incomplete and imperfect like life itself, including speculation (carefully identified as such) to fill in the holes in the evidence on the basis of tendencies identified in what evidence there is. But such history is certainly more meaningful to us than computer history, limited to the dry bones of statistics, and a lot more fun!

"Soft" data - here meaning accounts of conditions and events written or recounted by individual witnesses (not to exclude oral history) - all share great possibilities for error and distortion through the vagrancies of memory, misunderstanding, the informants' motives, which may be mixed indeed. Historians have good reason to be wary of such sources, which must be subjected to thorough critical analysis and used with great care. However, when properly tested against other available sources, such "soft" data have proved invaluable in establishing both objective facts and subjective attitudes of the time. If Olle Jönsson writes back to Småland that he voted the Republican ticket in a given election, and mentions several more times that he voted it again, while many Danes and Norwegians also write home with the same news; and if few or none of the letters extant mention that their writers have voted for other parties, then - after checking voting statistics in districts with heavy Scandinavian populations for key elections - I would feel confidence in accepting this "soft" evidence on which to build a generalization about the predominance of Republican party sympathy in the Scandinavian immigrant group. "Soft" evidence too can be counted in the matter of objective facts. Subjective attitudes are much more difficult to measure, of course, but the number of expressions of certain feelings (like homesickness) or attitudes (like rejection of American materialism) can be counted in proportion to the number of documents produced by a given group that are available. Some aspects of "soft" data can be computerized.

Of all kinds of "soft" data, literature has been the least used by historians, perhaps because many have assumed the same sharp line between fact and fiction that Hvidt insists on. The reader who has followed my argument so far, whether agreeing with it or not, should 
be prepared for my rejection of that sharp line both because I do not accept the absolute objectivity of "fact" and because I have read so much Scandinavian-American literature that describes the historical life of that group so vividly and accurately. I have spent years testing it against traditional historical accounts and materials, and it holds true Individual literary works vary greatly, to be sure, just as individual historical sources do, or individual accounts of anything in the present. The very first principle of any historian is never to believe any piece of evidence on its own merits, but to check it against anything and everything else available; and the second principle is, although nothing can ever be certain, the more witnesses who agree on a given point, the more likely that point is to be "true" ("what actually happened," "the fact," or whatever).

Kristian Hvidt complains that comparatively little source material has survived about Danish immigrant life in America except literature, but then forbids us to use that literature as historical source material, only as "an illustration of reality." Nonsense! Enough illustrations become evidence, and Scandinavian immigrant literature - also the Danish branch of it - is larger than he thinks. How much is enough is a hard question on which he and I would probably not agree, but fortunately I do not stand alone in this matter. Hvidt seems unaware of the growing attention to literature paid by historians, especially social historians, in recent years - not just fiction but all the literary genres, also poetry. These historians reject that what Hvidt calls the "damned question of representativity" can be answered only by statistics, by quantification of large numbers of cases. They hold that individual informants or small numbers of them can be representative of much larger numbers, like the "statistical samples" of subgroups in contemporary society used in social-science research and public-opinion polls. It then becomes of utmost importance for historians to establish the socio-economic and cultural background of the informants or witnesses, in order to judge if they represent or can speak for the various subgroups of the period under study. This is often difficult, but in my own field I have found it seldom impossible.

In an older day it was enough to use the records and writings of the ruling group, the elite of any period, but social history today insists on including "submerged" social groups like women, workers, minorities, children: the lower levels of society. Naturally source materials concerning these groups are very scarce, and most of them are literary. They have to be used, and this is the reason social historians have been using them more and more "in their own line of business." Hvidt is dead wrong when he says, "Historians dare not throw more than a shy glance at novels." That's only his kind of historian. It is not impossible to use literature as an historical source, only more difficult because of the aesthetic elements in literature that must be treated by special methods. Historians must have some training in literary criticism before they venture across the wavering line between fact and fiction

I wish I had space to discuss the major French and American historians who have been using literature very effectively in recent years, such as Herbert Gutman's analysis of poetry and sketches written by New England farm girls to throw light on how negatively they viewed their work situation when they took jobs in Lowell mills but still accepted it without protest. ${ }^{1}$ I must take time, however, to call attention in the work of two Scandinavian historians at least. One of these, Edvard Bull, has long been doing what Hvidt calls for: requiring his students of history to read fiction about the periods they are studying in order to "live themselves into" the consciousness then. The title of his paper at a 1976 conference, "Belles-lettres as Source Material for Social History," directly contradicts Hvidt.2 Bull maintains, and from my own research I agree, that authors are valuable as historical witnesses only when portraying periods they have lived in themselves. The historian must investigate what the author could know, and what he could not know, from his own experience. He must also investigate what the author could count on his readers knowing. This reader knowledge limited the author's imaginative freedom, for he could not violate with impunity what they considered to be fact. The historian must also judge the author's purpose in writing: whether to inform, to attack, too persuade or to entertain. This purpose will mold all his material, and must be taken into account.

Bull offers tentative "rules" for using this unaccustomed material, which I record because they agree fully with my own conclusions reached independently:

1. There is no direct connection between the work's literary quality and its usefulness as historical source

2. In autobiographical novels the descriptions of environment can be evaluated in the same way as memoirs.

3. Main characters who carry the plot, express the author's ideas, etc., are often more freely created than subordinate characters, who function to make the setting and milieu believable for the readers.

4. The most central elements in the work from a literary viewpoint are often more distant from reality than the minor motifs or themes.

5. A single literary work is only one report, and as such cannot give certain information about anything.

6. A writer is always an atypical person, and the more literary his background, the more atypical he is. ${ }^{3}$ 
Finally, Bull provides tentative answers to the question we are most concerned with here: what can literary source materials give to history? Information about how human beings in the past experienced the reality of their time, he puts first. Second he lists information about conventional and typical attitudes, opinions, and moral values. Children's books, literature of entertainment, and bestsellers are of special interest here. Third, he insists that literature also gives information about "external things." Some of Ibsen's plays record how maids in middle-class families in Norway at a certain period behaved toward their employers, for example, and how they were treated in turn. This would be common knowledge to contemporary Norwegian audiences, and Ibsen could not violate it. Finally, Bull also points out that literary source materials are cvidence of how people in the past were subjected to idcological influences, such as indoctrination (children's books) and propaganda (poetry of protest). Here he sees literature as more than a record, also functioning as a factor in historical causation to the extent that it influenced readers' attitudes toward societal change.

This paper was read at a conference on "Problems in the Interpretation of History" in 1976, where a second paper on "Literature and History" by Jarle Simensen was also read.4 While Bull affirmed the value of belles-lettres as record (beretning), Simensen emphasized its importance to the historian as document (leoning) from which to gain knowledge about the author and through him about his time. The historian must thus begin study of a literary work with a literary analysis. What literary conventions prevailed in that period, and what formal requirements does the genre impose on the author? What he has to say about his own time will vary greatly whether he has chosen to write a classical pocm, a romantic fable, a realistic novel, or science fiction. The realistic novel holds a special, central position as the best psychological documentation and source for the author's interpretation of his society. Historians should be interested in an author's experience of his time, says Simensen, because "the best authors are characterized by a special ability in observation, imaginative identification (innlevelse), and intuitive understanding of major relationships in their time." 5 They see more and understand better what they see than most people, even though they use this knowledge often for artistic and didactic ends that the historian must take into account. These are seldom difficult to identify by one trained in literary criticism.

The historian should also be interested in the author's attitudes as an expression of general attitudes in his time. Although he is atypical in his role as writer, this is no hindrance to his expression of widely accepted opinions. Simensen emphasizes that the historian must investigate the writer's background and beliefs to try to determine in what respects he is representative of certain groups in certain ways and in what respects he is individualistically himself. When the historian has judged the author's representability, he can then with greater confidence make use of the literary work as a source of idcology in its time. Finally, a work of literature can be treated as a cultural record. The author partakes in the general consciousness (meningsunivers) of his time, which molds his interpretations, his attitudes, and his use of language. For the historian a literary work thus provides a unique means of entry into the consciousness, the ways of thinking, of another timc, a different place, a strange society.

- I must disagree with Kristian Hvidt on one last point, his denial that literature can present any evidence for the reconstruction of "facts." I agree that literaturc cannot be used to establish specific facts - who did what, when, where. Typical facts, however, general conditions, the external and shared experiences of groups in many matters (such as family and institutional life - schools, churches, friendship groups, clubs and organizations): these aspects of life are reflected with considerable reliability in literature. The historian cannot accept uncritically the portrayal of such mattcrs, but if the author including them has proved to be a solid witness, or if many authors representing different subgroups and attitudes agree in their presentation of similar things, then I am convinced the historian can and should add such evidence to that of other sources in his construction of a picture of the past. Here literature provides data in the same way as other "soft" sources.

I began by welcoming Kristian Hvidt's essay as a sign that he had begun to realize the inadequacy of quantitative methodology in the study of history. His title gave me great hope in the phrase "the complementary study of history and literature." After working more closely through what he has said, however, I am not so sure he has changed much. Until he will accept that literature can do more than "illustrate" history, I fear we must continue to disagree. I advocate not the complementary study of history and literature, but history's use of literature as historical source material. 


\section{NOTES}

1. Herbert C. Gutman, Work, Culture, and Society in Industrializing America (New York: Alfred A. Knopf, 1976), pp. 26-29.

2. Edvard Bull, "Skjønnlitteratur som sosialhistorisk kildemateriale," in Förtolkningsproblem $i$ historia (Föredrag frăn Nordiska fackkonferansen för historisk metodlära på Hanaholmen i Esbo 23.-27. mai 1976) (Oslo: Universitetsforlaget, 1977), pp. 75-91.

3. Ibid., p. 89. My translation, with editing.

4. Jarle Simensen, "Diktning og historie," in Fortolkningsproblem i historia, pp. 92-98.

5. Ibid., p. 92. My translation. 